University of Wollongong

Research Online

Faculty of Commerce - Papers (Archive)

Faculty of Business and Law

$1-1-2009$

\title{
Value for money? Neo-liberalism in New South Wales prisons
}

Jane L. Andrew

University of Wollongong, jandrew@uow.edu.au

Damien Cahill

Follow this and additional works at: https://ro.uow.edu.au/commpapers

Part of the Business Commons, and the Social and Behavioral Sciences Commons

\section{Recommended Citation}

Andrew, Jane L. and Cahill, Damien: Value for money? Neo-liberalism in New South Wales prisons 2009, 144-152.

https://ro.uow.edu.au/commpapers/618

Research Online is the open access institutional repository for the University of Wollongong. For further information contact the UOW Library: research-pubs@uow.edu.au 


\title{
Value for money? Neo-liberalism in New South Wales prisons
}

\begin{abstract}
The NSW prison sector has undergone considerable reform over the last ten years. The NSW government now oversees the operation of publicly managed prisons, one privately managed prison and a number of new public prisons operating under the new 'Way Forward' management model. In order to establish which approach to prison management offered the best value for money, the NSW government undertook a 'value for money' assessment in 2005. In this article, we argue the cost accounting information is privileged in the assessment process. However, we contend that this information was limited and partial, and provided a poor basis on which to form policy. Even so, the NSW government has proceeded on this basis. In order to explain this, we position the report within the wider neo-liberal turn in policymaking and the workplace reforms that have accompanied it.
\end{abstract}

\section{Keywords}

value, wales, south, neo, prisons, money, liberalism

Disciplines

Business | Social and Behavioral Sciences

\section{Publication Details}

Andrew, J. L. \& Cahill, D. (2009). Value for money? Neo-liberalism in New South Wales prisons. Australian Accounting Review, 19 (2), 144-152. 


\section{Value for Money? Neo-Liberalism in New South Wales Prisons}

I n September 2005 the New South Wales (NSW) Parliament's Public Accounts Committee released a report entitled Value for Money from NSW Correctional Centres. The report considers three different approaches to correctional service delivery in NSW. These can be loosely categorised as public prisons; private prisons and a 'way forward' model that draws on elements of both. The report is part of a global trend whereby policymakers have sought to determine which mixture of private and/or public prison arrangements are the most efficient and effective (Schicor 1995; Cooper and Taylor 2005; Roth 2004; Andrew 2007).

We argue that this report is fundamentally flawed on its own terms. Although efficiency has many meanings, we posit the most significant measure of efficiency for the NSW government in its value for money assessment has been 'cost-effectiveness', rather than service delivery, and the stated 'corrective' objectives of incarceration. It is undeniable that cost-effectiveness is important in the design of any policy, but it is only ever part of the story (Newberry and Pallot 2003). In this case 'costeffectiveness' has been given such a central position that other issues that should be considered in the design of good prison policies have been neglected. Not only is cost considered central to the NSW government's prison policy recommendations, we show how the cost data used to build an understanding of the prison sector is flawed and based on assumptions that are not supported with externally verifiable evidence.

We also argue that the report positions workplace reform as the central innovation required for positive transformation of the prison system in NSW. Although other aspects of innovation are acknowledged, labour reform receives the most significant attention within all aspects of the report. While we recognise that the maintenance of a private prison in NSW has a number of objectives, our reading of this report suggests its primary purpose has been to discipline labour. It is an example of the use the private sector to achieve reforms within the public sector.

\section{New South Wales Prisons}

\section{Our Mission:}

Managing offenders in a safe, secure and humane manner and reduce risks of re-offending
The NSW prison sector has undergone considerable reform over the last ten years. The NSW government now oversees the operation of publicly managed prisons, one privately managed prison and a number of new public prisons operating under the new 'Way Forward' management model. In order to establish which approach to prison management offered the best value for money, the NSW government undertook a 'value for money' assessment in 2005. In this article, we argue the cost accounting information is privileged in the assessment process. However, we contend that this information was limited and partial, and provided a poor basis on which to form policy. Even so, the NSW government has proceeded on this basis. In order to explain this, we position the report within the wider neo-liberal turn in policymaking and the workplace reforms that have accompanied it.

\author{
Correspondence \\ Dr Jane Andrew, Senior Lecturer and Director of the Social \\ Accounting and Accountability Research Centre, School of \\ Accounting and Finance, The University of Wollongong, \\ Northfields Avenue, Wollongong NSW 2522. Tel: +61 2 \\ 4221 4009; email: jandrew@uow.edu.au
}

doi: 10.1111/j.1835-2561.2009.00052.x 


\section{Our Vision:}

Contribute to a safer community through quality correctional services

(NSW Department of Corrective Services, <www.dcs. nsw.gov.au/about_us/Mission_and_Vision.asp >, last accessed 17 April 2007)

The delivery, management and maintenance of prisons are no longer the exclusive domain of government. In 2007 , about $17 \%$ of the overall prison population of Australia was held in a private facility (Andrew 2007). NSW has adopted incarceration policies that have led to a prison population that in 2004-2005 was about 10\% above the national average (Auditor-General 2006). At the last census date, in June 2006, NSW held the largest number of prisoners in Australia, with approximately 9800 sentenced and unsentenced people incarcerated (<www.justiceaction.org.au/index.php?option $=\mathrm{com}_{-}$ content\&task=blogsection\&id $=9 \&$ Itemid $=30>$, last ac cessed 17 April 2007). Without a doubt, NSW incarceration policies place a significant burden on the prison system, and the state now has 35 correctional centres that need to be operated and maintained. None of these centres are identical. For instance, they vary in terms of size, security level, geographical location, the age of the infrastructure and the gender of the inmates. The ability of the government to maintain and expand prisons to meet the growing demand for prison space and services has caused considerable concern within the government.

\section{The Report: 'Value for Money'}

Despite the promise of cost reduction, much evidence shows that the cost differences between state and private prisons are insignificant. (Cooper and Taylor 2005, p. 506)

The Public Accounts Committee is an extension of the NSW Legislative Assembly, taking direction from ministers or the Auditor-General to scrutinise the 'efficiency and effectiveness' of government activities. In April 2005, the Public Accounts Committee began an inquiry into the 'value for money' of NSW correctional centres. The report states that 'value for money is usually defined as the efficient, effective and economic use of resources' (Public Accounts Committee Report No.156, 2005, p. iv); however, no definition of efficiency and effectiveness is provided. Considering the complexity of issues that surround the provision of correctional centres, most significantly their stated purpose (in NSW this is corrective) and the acceptable means through which this purpose can be obtained (such as the level of educational opportunities, work experience programs and drug rehabilitation considered appropriate to correct 'criminal' behaviour), it is noteworthy that a definition of 'efficient and effective' is not provided as this would help set up a basis for assessment. Although service quality and policy outcomes are essential to a determination of 'value for money', these are peripheral to the NSW report (2005). We argue that this enables the report to position cost-effectiveness at the heart of NSW prison policy and legitimises public debate that focuses on this issue, while delegitimising alternative criteria for assessment, such as safety, educational outcomes or low recidivism (in NSW about $40 \%$ of people released from prison return to serve a sentence within two years) (Auditor General 2002; Andrew 2007).

\section{Cost over value?}

'Value for money' is an increasingly popular approach to assessing the 'value' of current and future government policies and projects (Jacobs 1998). Considering its significance it is surprising that it has not been clearly defined within the literature and that the terms of assessment remain ambiguous (Grimsey and Lewis 2005). In general, value for money has involved the assessing of the cost and quality trade-off to determine the viability of a current or potential project in terms of its stated objectives. Unfortunately, for the most part this interpretation is not one that has been adopted by governments in their assessments. According to Grimsey and Lewis (2005, p. 375) 'the value for money test frequently comes down to a simple, single point comparison between two procurement options...the problem is that value for money is more often than not poorly understood and often equated with the lowest cost'.

The report 'Value for Money from NSW Correctional Centres' (Public Accounts Committee Report No. 156, 2005) substantiates the argument that value is being equated with cost. In this report, there was no discussion of what may constitute 'value'. Instead it was assumed throughout the report that cost and value are ostensibly synonymous. This privileging of 'cost' is evident from the outset and is embedded in the report's terms of reference, which begins with two objectives that state the report will make cost comparisons within and across the sector. Somewhat paradoxically, the third objective of the report focuses on the development of appropriate costing methods that enable such comparisons. The report acknowledges the difficulties associated with costing and cost comparisons within the sector, but states clearly that despite this, 'the focus of this inquiry is on the financial aspects of value for money' (Public Accounts Committee Report No.156, 2005, p. 14). It is also apparent from the terms of reference that, apart from safety considerations, other markers of 'value', such as the quality of the services provided, will not be the focus of the report. Specifically, the terms of reference state that the report should: 
1. Consider the current initiatives being undertaken by the Department of Corrective Services (DCS) to improve safety and cost effectiveness of correctional centre management;

2. Compare the cost of corrective services provided by public correctional centres using the Way Forward program and by private operators; and

3. Review whether the planned improvements to the DCS calculation of costs will facilitate better comparisons between private and public sector providers (Public Accounts Committee, Report No.13/53 (No.156), 2005, p. iv).

These terms of reference offer an implicit recognition that cost comparisons cannot be made. However, it is important to acknowledge that qualitative matters are considered to some extent within the report, but we contend that the report is written in such a way that this is a marginal concern. Unlike cost, quality information is seen to be relatively easy to compare and as a result does not present the same difficulties in a value assessment as those related to its cost. It is well documented that the cost data available are limited and the nature of the sector makes any such direct comparison all but impossible (Roth 2004). It is also apparent that 'value for money' is ill-defined and, as shall be argued, it is questionable whether realistic cost comparisons and assessments are the motivation for such a report. However, it does enable policymakers to reaffirm cost as the central policy consideration and relegate other issues into the margins of public debate (Andrew 2007). It also allows the government an opportunity to position new workplace changes to the sector in 'neutral' cost terms (as discussed later). Although we acknowledge that the terms of reference of all reports must be limited, we consider the boundaries of this report to be part of a strategy to position cost at the heart of prison policy discussions.

\section{Partial cost?}

Not only does the report focus on cost rather than 'value', the cost data that are provided is inadequate. The report begins with an outline of inmate costs per day, which represents the costs in a way that fails to acknowledge their partiality and ambiguity. The table appearing on page one of the report (Table 1, shown below), suggests the cost per day to incarcerate a person in a private prison
(Junee) is almost half the cost per day of incarceration in a public prison. This table frames the discussion that takes place in the remainder of the report, and although the limitations of this data are mentioned, it is nonetheless on this basis that the report proceeds.

If the information presented in Table 1 were adequate, presenting accurate and comparable cost data, it would be logical to conclude that private prisons are cheaper. If we conclude that they were cheaper, it would be possible to argue they were more efficient and therefore a better use of public funds if this were accepted as the criteria for assessment. However, the story is not this simple. Although the table may be strikingly effective in creating an impression of private prison cost-effectiveness, the information is flawed on many levels.

First, the representation of the average cost per inmate per day in the Junee private prison cannot be substantiated with any externally verifiable evidence. The report states in a footnote:

\footnotetext{
These figures were not in the Auditor-General's Reports to Parliament. They have been calculated by dividing the quoted annual cost amounts by the number of days in the year. This is the cost to DCS; i.e the management fee plus the allocation of department overheads and not the actual cost to the private operator. (Public Accounts Committee Report No.156, 2005, p. 1)
}

These figures have been created for this report, yet there is no detailed explanation as to what constitutes the figures. The Auditor-General's report (2002) didn't include this figure because it was considered too difficult to determine. As the comparative data provided in this table are central to the presentation of the discussion within the report, it would seem appropriate that the Public Accounts Committee substantiate its calculation. Significantly, the allocation of departmental overheads is never completely clear and requires management accountants to make decisions as to how these should be reflected in their accounts. There is much room for distortion and manipulation here, and although the report claims the 'cost per inmate' includes overheads, we are not told what proportion of the Department of Corrective Service's overheads were attributed to the private operator. This complexity of cost allocations is widely acknowledged within the literature (Alam and Lawrence 1994; Doost 1997). For instance, Marshall (1994, p. 12) argued that 'when overhead is allocated, costs become politicized'. Considering that the report

Table 1 Average costs per inmate (taken from the Public Accounts Committee Report 2005)

\begin{tabular}{llrrr}
\hline & & $2001-02$ & $2002-03$ & $2003-04$ \\
\hline Department of Corrective Services & Average cost per inmate per day & $\$ 167.85$ & $\$ 187.00$ & $\$ 187.80$ \\
Junee Correctional Centre & Average cost per inmate per day & $\$ 92.04$ & $\$ 93.54$ & $\$ 91.75$ \\
\hline
\end{tabular}


proceeds on this basis, it is of concern that these cost allocations are not discussed in more detail.

Second, the report relies heavily on the AuditorGeneral's reports to Parliament; however, in the presentation of this cost data the report downplays the inadequacy of this information. For example, the Auditor-General (2002) stated that the weighted average cost of an inmate held in one of the state's publicly run prisons in 2001-2002 was \$61 265 per year. However, the cost of an inmate held in the state's private prison at Junee was \$33 595 per year. Significantly, the AuditorGeneral's 2002 report states that 'this cost cannot be readily compared to the weighted average cost for the Department of $\$ 61,265$, as that cost incorporates additional overhead and program costs' (AuditorGeneral 2002, p. 125). The nature of these overheads and program costs are not revealed, but it is clear that the calculation of the figure for Junee includes little more than the direct management of the prison. It is unclear how these figures deal with the costs incurred through the process of overseeing the individual prisons and the sector more broadly; the costs associated with contract compliance and design costs; and the cost of the building and grounds that are born by the government.

It is also apparent that Junee has been running below capacity, yet the management fee is fixed irrespective of the number of prisoners held there:

Over the year, the privately operated correctional centre at Junee operated at 94.0 per cent of its capacity... The management fee is fixed, and is based on providing accommodation for 682 inmates. (Auditor-General 2002, p. 125)

Using simple strategies, these cost data distort the representation of the efficiency of the private operator. For instance, the cost per capita for 2001-2002 at the Junee Correctional Centre is based on a capacity of 682 prisoners, when in fact there were only 641 prisoners. Obviously, if the prison is being paid a set amount, yet needs to provide less service, the cost data will be distorted. The fact they were allowed to operate below capacity is also interesting, considering state prisons have been overcrowded, leading to other cost implications related to the maintenance of a safe, orderly prison when there are too many people in it (NSW Legislative Council 2001).

When cost comparisons are being constructed, it is important to acknowledge that the cost per day of housing prisoners is substantially different depending on their classification. This is apparent when state-operated prisons are compared to each other. These per capita cost figures vary significantly; for instance, it costs $\$ 421.79$ per day to house a prisoner in the Special Purpose Centre at Long Bay, whereas it costs only $\$ 115.01$ per day at a minimum security prison (Auditor-General 2004).
This is equally true of the costs used to compare the Department of Corrective Services (DCS) to Junee. The figures appear to vary widely, with the private operator appearing substantially more cost-effective; however, this needs to be placed within the context of a very diverse correctional system. The fact that the figures vary widely is not evidence in and of itself, because as we have shown, the cost figures will vary depending on the nature of the costs included in the figure and the type of prisoners/prison being compared.

\section{Secret efficiencies}

The actual internal operating efficiencies of the private operator are not made publicly available. The Public Accounts Committee Report states 'the actual operating costs for Junee are not available as GEO is a private company that is in competition with other operators in Australia and this information is commercially sensitive (2005, p. 23). This statement reveals just how little evidence the government has available regarding the operational efficiencies of the private operator and what strategies it is using to meet its contractual and regulatory responsibilities, and also ensure a profit for its shareholders. Although the public may be interested only in the amount it costs to provide public or private prisons, the internal efficiencies are still relevant. There are many examples of arrangements that may be made by private providers in order to meet their broad contractual obligations at the lowest cost. For instance, one provider sourced much of the internal furnishing and clothing for the prison through a charity (see Andrew 2007). How a prison manages to minimise costs is fundamental to an accurate assessment of the prison's performance, and this may not be reflected in a tick of the box style accountability that contractual compliance audits rely on. Arguably, private prisons are at a strategic advantage if they are able to keep much of their operations confidential, as the public sector competitors are required to make much of this information publicly available.

To presume efficiency and proceed on this basis is entirely insufficient, as is the argument that private operators encourage innovation if that innovation is a corporate secret and it will not be possible to use it to influence the development of the sector.

Based on this discussion we argue that the privileging of cost over value, the partiality of the costing offered within the report, and the secrecy surrounding the private operators' efficiencies undermine the legitimacy of the report on its own terms. As the report proceeds on the basis of what we have shown to be inadequate, and, at times misleading, information, we suggest that the report legitimises strategic policy initiatives through the use of what is presented as 'neutral' cost accounting. 


\section{Neo-liberalism and NSW Prisons}

It has been argued that the report Value for Money from NSW Correctional Centres provides little sound basis for a reasonable cost comparison between the public and private forms of prison operation under the NSW government's jurisdiction. Nonetheless, the report found that the privatised Junee prison offered superior cost-effectiveness to that of the publicly managed prisons. Using this finding as a justification, the report recommended that at least one private prison should be maintained in NSW to serve as a benchmark against which the publicly operated prisons could be evaluated. The obvious question arising from this seemingly paradoxical outcome is: why did the report find the privately operated prison to be superior in terms of costeffectiveness when insufficient evidence existed to make such a case? It is to answering this question that we now turn.

The use of private entities to provide correctional services in NSW is part of a global neo-liberal shift in policymaking. Although the shift to this kind of policymaking has emerged unevenly, during the past 20 years, neo-liberalism has become the globally dominant 'rationality of government' (Dean and Hindess 1998). As a theory of governance, neo-liberalism (or synonymous processes such as 'economic rationalism' and 'economic reform') argues that markets are, in general, the most efficient means of providing a host of social services traditionally undertaken by governments. The rise of neo-liberalism has seen the proliferation of processes such as privatisation, deregulation and marketisation for delivering public services. This rise is often explained as a consequence of the triumph of a particular set of ideas about policymaking (see, for example, Yergin and Stanislaw 1998; Pusey 1991; Funnell 2001). According to this account, the 'Keynesian' consensus in policymaking that prevailed in most capitalist countries during the post-World War II boom, and which entailed a strong role for government in the regulation of economic activity, was superseded, as policymakers came under the sway of the neo-liberal worldview. According to this argument, neo-liberalism has therefore become the dominant logic of policymaking.

Such an analysis provides one possible explanation for the findings of the Value for Money from NSW Correctional Centres report. If neo-liberalism constitutes the triumph of a particular ideology, and has become the dominant logic of policymaking globally, then in prioritising the private prison model the NSW government is, it could be argued, simply following this dominant logic. The paradigmatic dominance of neoliberalism would help explain why the government is seemingly blind to the lack of evidence that informs its decision.
In fact, this is the same general argument in relation to neo-liberalism that has been put by many of its critics. It is argued that the capture of policymaking elites by neo-liberal modes of thought helps to explain why, what such authors view as, an irrational ideology, dominates policymaking. Pusey (1991, p. 8) for example argues that ' $(\mathrm{t})$ he process of reform and rationalisation is driven by an intellectual triumph of formal models over practical substance', while Funnell $(2001$, p. 1) writes, '( $\mathrm{t}$ )hroughout the Western world liberal democratic governments have transformed themselves in the image of the private sector and according to the beliefs of neoliberal ideologies'. While this explanation no doubt has some merit, it ultimately relies upon the assumption that governments have been captured by an ideology that renders them blind to their own irrational decisionmaking processes. In this case, to decisions based upon inadequate cost accounting information.

In contrast we posit an alternative explanation that emphasises the strategic aspects of the Value for Money from NSW Correctional Centres report. This is not to deny the importance of ideas in influencing policymaking, nor the potentially socially deleterious and unintended consequences of neo-liberal policy, nor the potential for policymakers to make irrational and ill-conceived policy decisions. Rather, it is to go beyond such explanations and to recognise that rhetorical commitment to certain philosophies of government - such as neo-liberalism or new public management (Newberry 2004; Newberry and Pallot 2003) - often belies the strategic political motivations that underpin policy decisions.

\section{The 'Way Forward'}

...(t)he proposed cost savings were illusory. Furthermore, the underlying objectives driving the proposals... were more complex than the apparently transparent aim of saving money and providing value for money (VFM). Behind the rhetoric we discern the erosion of public sector pay and conditions and the transfer of wealth from the public to private sector through the perpetuation of a particular type of prison regime. (Cooper and Taylor 2005, p. 501)

The previous discussion has illustrated how the cost data presented provide an inadequate basis of assessment. However, these data play a vital role in constituting the terms of debate, offering visibility and legitimacy to cost comparisons that are partial at best. It also legitimises the development of 'cost minimisation' strategies, making significant reforms possible within a debate that has been captured by these terms.

We argue that this is strategic and is not an accidental consequence of policy investigations and government reports. It is the inevitable consequence of reports that are framed almost entirely within the limited 
parameters of cost-effectiveness. One outcome of this has been the development of the 'Way Forward' Workplace reform within the public prison system, which has been operating in the states' two new prisons at Kempsey and Dillwynia since 2004.

According to the report, the 'main benefits' of the 'Way Forward' model are:

... reduced overtime, reduced sick leave and streamlining of operational functions. This has resulted in significant cost savings when compared with correctional centres operating under the traditional model. Other advantages include improved security and safety for both staff and inmates and increased rehabilitation opportunities. (Public Accounts Committee, 2005, p. 15)

While greater cost-efficiency is the acknowledged aim of the 'Way Forward' model, a closer reading of the Value for Money from NSW Correctional Centres report reveals a broader agenda. The report states that Memorandums of Understanding based upon the 'Way Forward Model' will be introduced in the future to replace existing 'Operational Agreements' in order to:

- Consult staff on matters related to safety and workplace relations;

- Increase flexibility of management to pursue operational and economic key performance measures; and

- Reduce the union focus on maximizing overtime in future award negotiations. (Public Accounts Committee, 2005, p. 16)

The last two points are revealing. They suggest that the broader goals of the 'Way Forward' program are greater managerial flexibility and a reduction in the purview of union demands. Increased managerial flexibility is noted in the document as an outcome of the 'Way Forward' model. For example, the 'let go' and 'lock in' process 'allows more flexibility in managing staff resources... This has resulted in overtime not being the only solution to staff shortages' (Public Accounts Committee Report, 2005, p. 17). Similarly, changes to the operation of court cells within correctional centres means that: 'staff can be redeployed between centres and court cells to meet needs on a day to day basis. This will allow greater flexibility in staff management and reduce operating costs' (Public Accounts Committee Report, 2005, p. 18). Furthermore, the proposed centralisation of staff rostering under the 'Way Forward' model gives greater power for the DCS to manage staff hours without incurring overtime costs and curtails the ability of prison staff to influence rostering decisions. The 'Way Forward' model therefore points to a regime of greater managerial prerogatives, increased flexibility of management in the deployment of labour, potential cost savings through the reduction in over-time and sick leave, and a diminution in union influence over these issues.

These reforms were negotiated using data that illustrated the cost-effectiveness of the private model, and the labour-related inefficiencies of the public model. Throughout these negotiations the government maintained its right to offer the new prisons to private tenders if the negotiations were not successful. The union representing prison staff, the Prison Officers Vocational Branch (POVB) of the Public Service Association, reported to its members that during negotiations over the 'Way Forward' model, 'At all times hovering in the background is the spectre of privatisation. The Government through Treasury has made it plain that privatisation will follow if agreement on working conditions, etc, is not achieved between the Union and the department' (Public Services Association 2004). The POVB also claimed that 'all available sources of information confirmed the threat that the new prisons were to be operated by the private sector' (CPSU-SPSF 2004). One of these sources was John Hatzistergos, Minister for Correctional Services, who informed union officials at a meeting on 10 September 2003 that 'private prison operations are continually approaching the government for work' (CPSU-SPSF 2003). It was in this context that the 'Way Forward' reforms were agreed to by the union. At the time, POVB official John Scullion, argued that the agreement ensured 'that more than 500 jobs remain in the public sector' (CPSU-SPSF 2004).

In effect, it seems that the government used the possibility of further privatisation as a threat to discipline the union representing prison staff into ceding to the government's Way Forward model. There is implicit acknowledgement of this in the Value for Money from NSW Correctional Centres report:

There was early speculation that the new correctional
centres at Kempsey and Dilwynia would be privatized.
Around the same time, DCS was negotiating with
the Prison Officers Vocational Branch (POVB) of
the Public Service Association to introduce the 'Way
Forward' workplace reform to improve the efficiency
and effectiveness of the public system. The negotiations
with the union proved successful and a new consent
award was established to cover these new facilities.
Subsequently in March 2004, the NSW Government
approved the public operation of the new correctional
centres' (Public Accounts Committee Report 2005,
p. 19).

In light of this, the cost-effectiveness of the private sector is almost irrelevant - the maintenance of an alternative prison policy possibility offers the government a tool to instigate workplace reform, while maintaining an appearance of rationality and neutrality (Dillard 
1991). This is embodied in one of the report's key recommendations:

Recommendation 4: The Government should maintain at least one private prison in the State for the purposes of benchmarking the performance of publicly operated centres and to encourage the development of innovative management strategies" (Public Accounts Committee 2005, p. vii).

If we can rule out cost-effectiveness as the primary purpose for maintaining private prisons in NSW, the more revealing issues relate to workplace reforms. It seems, at the very least, plausible to suggest that the existence of the private prison at Junee acted as a disciplinary device to pressure the union into accepting the 'Way Forward' model, which ceded greater flexibility and prerogative to prison management and reduced the influence of the union over staffing.

When Junee opened in 1993, the government intended for it to provide a benchmark for the public sector and according to Roth (2004) the future direction of prison management was heavily influenced by this decision. When the company was awarded a second contract in 2001, this was seen as a sign of success that paved the way for much speculation about the management of future prisons. According to the Public Services Association, which represents the public sector prison officers, the decision to open publicly managed prisons in the future rested entirely on their agreement to substantial workplace reforms. Most significantly they agreed to be paid a flat rate for overtime.

This is a position that was clear even before the construction of Junee had begun, when in September 1989 the Kleinwort Benson Report (1989) recommended to the state government that it approve the operation of privately run prisons. The report stated that changes in prison management would be accelerated through the use of a private prison, and that it would provide an effective benchmark to assess the efficiency of other prisons within the sector. The report was endorsed by the NSW state government, and it decided to recommend that a medium security prison be built in Junee rather than the maximum security prison initially intended in order to facilitate privatisation.

Strong causal links between neo-liberal agendas and workplace reforms have been noted elsewhere. For example, Cooper and Taylor (2005), in a study of prison privatisation in Scotland, identify reducing labour costs and increasing labour flexibilities as a key reason for privatisations. We contend that, in the specific case of the New South Wales Value for Money from NSW Correctional Centres report, the government's support for the maintenance of 'at least one private prison', in the absence of meaningful cost data, was on the basis of the continuing disciplinary effects it would have upon the union, and therefore the leverage it would grant the government in extending its workplace reform agenda. In this context, the private prison acts as a form of 'indirect regulation', meaning 'the capacity of the state to regulate through a range of alternative mechanisms other than formal rules (Gahan and Brosnan 2006, p. 133). In this case, privatisation is used for the indirect regulation of labour by the state.

That such processes might occur under a system of neo-liberalism is consonant with recent scholarly literature. A number of theorists, for example, note the discrepancy between the ideology of neo-liberalism, and the policies enacted by neo-liberal governments (Anderson 1999; Brenner and Theodore 2002; Cahill and Beder 2005; Harvey 2005). Indeed, a striking feature of neo-liberal policymaking globally has been the construction of a new and pervasive set of regulatory apparatuses. While the 'retreat of the state' (Strange 1996) has often been understood as a consequence of neo-liberalism, the experience of the last 20 years has been the reconfiguration, not the diminution, of state regulations (Harvey 2005, p. 78; Cahill and Beder 2005). It was such observations that led Brenner and Theodore (2002) to coin the term 'actually existing neo-liberalism', in order to distinguish the real-world policy regimes of neo-liberal states from the predicted outcomes of neoliberalism put forward by many of its supporters and detractors alike. Similarly, Anderson (1999) argues that the neo-liberal process of 'deregulation' often entails a social and market 're-regulation'.

It is through such a conception of neo-liberalism that, we argue, a more nuanced understanding of the 'Value for money' document is possible. Close examination of the Value for Money from NSW Correctional Centres report reveals the operation of 'actually existing' neoliberal processes that re-regulate labour in the interests of management. This is in keeping with scholarly analysis of neo-liberal labour market deregulation in Australia, which argues that governments have been empowered to regulate labour in a range of new ways (Anderson 1999; Ellem 2006). That the NSW correctional system embodies a hybrid model of privatised and governmentoperated prisons reflects the 'uneven geographical development of neo-liberalism' (Harvey 2005). The Value for Money from NSW Correctional Centres report also highlights the ways that accounting practices have been used as vehicles for the implementation of neoliberal agendas globally (Newberry 2004; Newberry and Pallot 2003; Cooper and Taylor 2005).

\section{Conclusion}

A critical examination of the NSW government's Value for Money from NSW Correctional Centres report into prisons reveals that the cost data presented provides 
an inadequate basis for policy decisions about the appropriate mix of public and private management of prisons in NSW. That the cost data were found wanting prompts the question of why the privatised model of prison management was held to deliver superior 'value for money'. One possible answer to this question is that the government has been influenced by neo-liberal theories of policymaking to such an extent that it prioritises private over public forms of management even when there is little cost data to support the neo-liberal belief that privatised modes of service delivery are inherently more efficient than public modes. While not denying the influence of neo-liberal ideology upon policymakers, this article has argued that a more plausible explanation is to be found in the disciplinary leverage afforded to the government over unions in negotiations over workplace reform through the ongoing existence of a privatised prisons in NSW. This highlights the ways in which the presentation of accounting information can mask power relations and political agendas, and therefore that critical analytical tools have an important role to play in their interpretation.

Jane Andrew is in the School of Accounting and Finance, Faculty of Commerce, University of Wollongong, and Damien Cahill is in the Discipline of Political Economy, Faculty of Arts, University of Sydney. They thank the two anonymous reviewers and the participants in the 2008 Critical Perspectives on Accounting Conference whose comments have helped clarify and improve this article.

\section{References}

Alam, M. and Lawrence, S. 1994, 'A New Era in Costing and Budgeting: Implications of Health Sector Reform in New Zealand', International Journal of Public Sector Management, 7, 6: 41-51.

Anderson, T. 1999, 'The Meaning of Deregulation', Journal of Australian Political Economy, 44: 5-21.

Andrew, J. 2007, 'Prisons, the Profit Motive and Other Challenges to Accountability', Critical Perspectives on Accounting, 18: 877-904.

Auditor-General, Auditor-General's Report to Parliament 2002, Volume 6, NSW Audit Office, Sydney.

Auditor-General, Auditor-General's Report to Parliament 2004, Volume 4, NSW Audit Office, Sydney.

Auditor-General, Auditor-General's Report to Parliament 2006, Volume 4, NSW Audit Office, Sydney.

Brenner, N. and Theodore, N. 2002, 'Cities and the Geographies of 'Actually Existing Neoliberalism', Antipode, 34, 3: 349-79.
Cahill, D. and Beder, S. 2005, 'Regulating the Power Shift: The State, Capital, and Electricity Privatisation in Australia', Journal of Australian Political Economy, 55, June.

Cooper, C. and Taylor, P. 2005, 'Independently Verified Reductionism: Prison Privatization in Scotland', Human Relations, 58, 4: 497-522.

CPSU-SPSF (2003) 'Union Executive Response to "Way Forward” Proposal', CPSU website, available at: <http://cpsuspsf.asn.au/campaigns/corr_services/20030914_159.html >. Last accessed 4 April 2008.

CPSU-SPSF (2004) 'Public Union Best for Gaols: PSA Retains Coverage of NSW Correctional Centres', CPSU website, available at: <http://cpsu-spsf.asn.au/latest_news/ corr_services/20040304_Prisons.html>. Last accessed 4 April 2008.

Dean, M. and Hindess, B. 1998, Governing Australia: Studies in Contemporary Rationalities of Government, Cambridge University Press, Melbourne.

Dillard, D. 1991, 'Accounting as a Critical Social Science', Accounting, Auditing and Accountability Journal, 4, 1: 8-28.

Doost, R.K. 1997, 'What Is Our University Overhead Cost Anyway?', Managerial Auditing Journal, 12, 2: 94-7.

Ellem, B. 2006, 'Beyond Industrial Relations: Workchoices and the Reshaping of Labour, Class and the Commonwealth', Labour History, May: 211-20.

Funnell, W. 2001, Government by Fiat: The Retreat from Responsibility, UNSW Press, Sydney.

Gahan, P. and Brosnan, P. 2006, 'The Repertoires of Labour Market Regulation', in Labour Law and Labour Market Regulation, C. Arup et. al. (eds), The Federation Press, Sydney: 127-46.

Grimsey, D. and Lewis, M.V. 2005, 'Are Public Private Partnerships Value for Money? Evaluating Alternative Approaches and Comparing Academic and Practitioner Views', Accounting Forum, 29: 345-78.

Harvey, D. 2005, A Brief History of Neoliberalism, Oxford University Press, New York.

Jacobs, K. 1998, 'Value for Money Auditing in New Zealand: Competing for Control in the Public Sector', British Accounting Review, 30: 343-60.

Kleinwort Benson Report (1989), Investigation into Private Sector Involvement in the New South Wales Corrective Services System: Stage 1, The Department of Corrective Services, Sydney.

Marshall, G. 1994, 'The Problem with Allocations', CFO, 10, 8: 12 .

Newberry, S. (2004), 'Trade in Services: Wider implications for Accounting Standard Setters and Accountants', Australian Accounting Review, 14, 2: 11-21.

Newberry, S and Pallot, J. 2003, 'Fiscal (ir)responsibility: Privileging PPPs in New Zealand', Accounting, Auditing and Accountability Journal, 16, 3: 467-92. 
NSW Department of Corrective Services, <http://www.dcs. nsw.gov.au/about_us/Mission_and_Vision.asp $>$. Last accessed 17 April 2007.

NSW Legislative Council, November 2001, 'Select Committee on the Increase in Prisoner Population', Parliamentary Paper Number 924, Parliament of NSW, Sydney.

Public Accounts Committee 2005, Value for Money from NSW Correctional Centres, Report no. 156, Parliamentary Papers, no. 53/13, September, New South Wales Parliament, Legislative Assembly, Australia.

Public Services Association 2004, 'The Way Forward', media release, available at $<$ http://www.psa.labor.net.au/news/ 1076386158_24818.html>. Last accessed 4/4/08.
Pusey, M. 1991, Economic Rationalism in Canberra: A Nation Building State Changes Its Mind, Cambridge University Press, Cambridge.

Roth L. 2004, 'Privatisation of Prisons: Background Paper', 3/2004, Parliament of NSW, Sydeny.

Shichor D. 1995, 'Punishment for Profit: Private Prisons/public Concerns', SAGE Publications, US.

Strange, S. 1996, The Retreat of the State: The Diffusion of Power in the World Economy, Cambridge University Press, Cambridge.

Yergin, D. and Stanislaw, J. 1998, The Commanding Heights: The Battle Between Government and the Marketplace that is Remaking the Modern World, Simon and Schuster, New York. 